\title{
Development of Solid Waste Management Plan to Solve the Transport Routes Problem in Baghdad City Ayad Naeem Sadoon ${ }^{1}$, Ali H. Kadhum², Amjad Barzan Abdulghafour ${ }^{3}$
}

\author{
Authors affiliations: \\ 1) Advance Manufacturing \\ Systems Eng. Dept., Al- \\ Khwarizmi Eng. College, \\ University of Baghdad, Iraq. \\ Ayadnasry602@gmail.com \\ 2) Advance Manufacturing \\ Systems Eng. Dept., Al- \\ Khwarizmi Eng. College, \\ University of Baghdad, Iraq. \\ kadhumali59@yahoo.com \\ 3) Production and Metals Eng. \\ Dept., University of \\ Technology, Baghdad, Iraq. \\ amjad barzan@yahoo.com
}

\section{Paper History:}

Received: $10^{\text {th }}$ Feb. 2020

Revised: $3^{\text {rd }}$ March 2020

Accepted: $16^{\text {th }}$ March 2020

\section{Introduction}

Currently, SWM is considered as one of the

\begin{abstract}
The transportation cost problem of solid waste presents the biggest part of the budget allocated by municipalities for SWM. So, there is no comprehensive plan to address transport routes optimization problems in SWM that including the transfer of solid waste from transfer stations to final landfill sites. Therefore, the aim of the study finding a scientific method to solve the transportation problem of solid waste transport suitable Baghdad city that tries to find feasible solutions that ensure reducing total transport costs and leads to an effective solid waste management system. In this research, a new methodology has been developed to select the optimal transport routs of SWM in Baghdad city which involves determining the best-supposed scenario. the proposed methodology includes integration of Global Positioning System (GPS) technologies with Network Analysis model (NA). Therefore, this work provides an advanced framework of decision-makers for analysis and simulation of the optimal transport routs problem related to SWM. Applying these modeling tools to select the scenario that can provide economic benefits by minimizing travel time, travel distance and reduction of total transportation costs. The Results of work implementation show that all solutions that include current state $\mathrm{S} 1$ and suggested scenarios have been evaluated. The scenarios generated include (S2, S3) by applying the proposed technique for analyzed and identified the optimal routes. The solutions of scenario S2, specified with two landfill sites while scenarios S3 specified with four landfill sites. Finally, this work shows the Scenario S3 is the best scenario of the solution, that include applied GPS and Network Analysis for four landfill sites.
\end{abstract}

Keywords: Solid Waste Management, GPS, Network Analysis, Transportation Route.

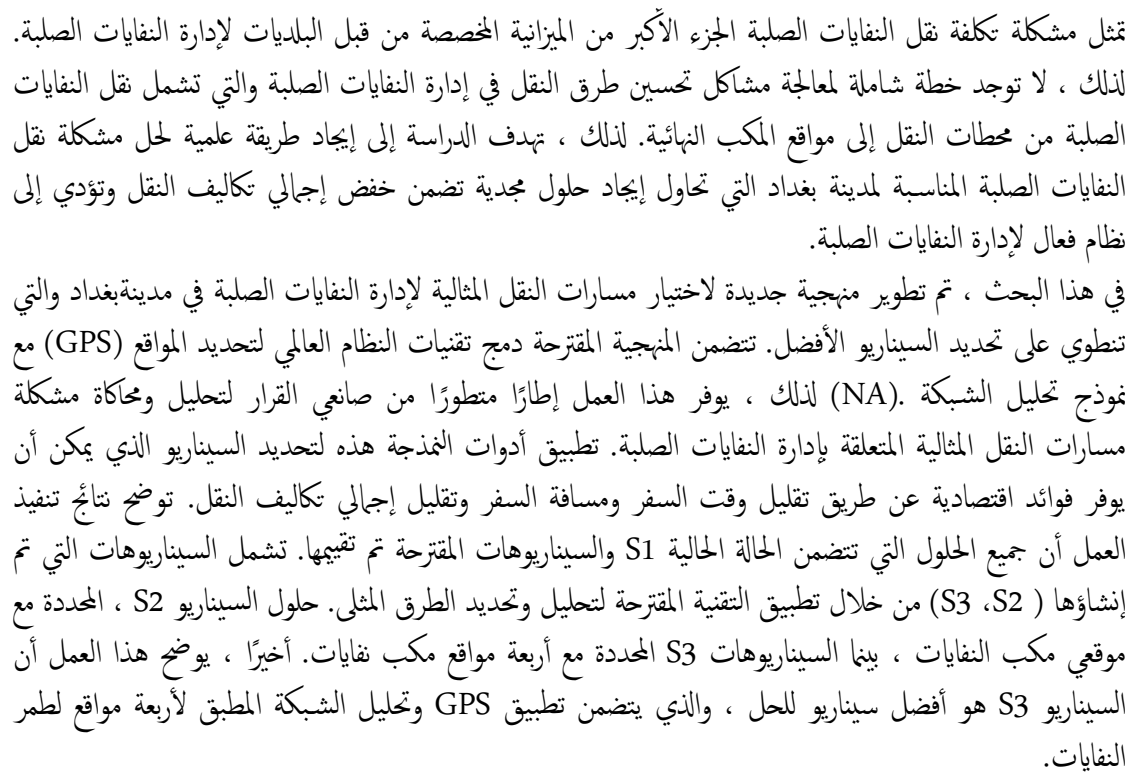
main problems in the world. Infrastructure, residential and commercial developments are 
increased because of the growth in and it results in bad impact on environment. The There are several technologies that are used for solving SWM's problem and how to decrease its cost. It contains several positions to study such as a collection of waste, transfer station, recycling, processing, and landfill. Solid waste transportation and disposal is the most important problem facing cities and urban communities in the world. The quantities of solid waste are increasing day by day compared to the previous days due to the increase in population and high standard of living. Therefore, the increase in the amount of solid waste can cause pollution of the environment elements of land, water, and air, as well as the depletion of natural resources. If not calculated and submitted in recognition of true may result in serious damage and losses cannot be compensated [1]. Baghdad city is currently suffering from the mismanagement of thousands of tons of solid waste generated daily and the adoption of incorrect methods in the process of transporting waste from the transfer stations to the final landfill sites. This resulted in wasted costs, inefficient disposal of waste and pressure on the transport network due to multiple trips to transport these large quantities generated daily. The study aims to determine the feasibility of the proposed methodology of the current position transport of solid waste in Baghdad city and recognition on the most important problems that Baghdad honesty faces them in the process of manage solid waste, therefor in this research developing a new methodology to transport solid waste from transformer stations to final landfill sites to find the optimal Routes an to decrease distance, time and the cost of transporting solid waste.

The transportation cost of solid waste has been reduced by managing and optimizing the waste transportation route. At present work, the cost is considered as the main criterion to select the solid waste transportation route. The proposed technique is used the network model to analyze the data obtained from the GPS to select the best transfer route. A new mechanism for the distribution of municipalities around the landfill stations leads to a decrease in the cost of disposing of solid waste.

This research will deal with the previous work that takes the Solid Waste Management (SWM) as a research topic, and it will address the most important researches in the field of SMW.

M. Matotek and D. Regodic, 2013[2] demonstrated the usability of possibilities of the WinQSB software package for application in transport management in companies where is necessary to take care of the reduction of transport charges.

J. E. Santibañez-Aguilar et al, 2013[3] used a mathematical programming model for the optimal planning of the supply chain associated with the MSW management system to maximize the economic benefit. The problem was formulated as a multi-objective linear programming problem, where the results are shown through Pareto curves that tradeoff economic and environmental aspect.

O. I. Amariei et at, 2015[4] used sub-modules of Network Modeling from WinQSB software to Minimizing transport distances, costs, and study of the effect which have a certain transport unit cost over the transport optimal program to realizing an optimal distribution of products to final beneficiaries.

N. Sh. Hadi (2015) [5] utilized the strategy for Vogel estimated model of transport for access to a lower cost of transport strong waste created from regions to landfill locales, so any improvement in the vehicle framework will prompt reserve funds in transport costs.

T. P. B. Vecchi et al, 2016 [6] The main objective of this paper present a sequential approach involving three phases for solving the optimization problem of truck routes for the collection of solid waste. The proposed methodology was tested using real data and efficiently solved the problem. The results led to a reduction in the distances traveled by trucks, which could promote money savings for the public coffers, as well as a reduction in carbon dioxide emissions.

M. Rabbani et al, 2016 [7] proposed a various leveled structure to limit the all-out cost of waste assortment directing issues. In addition, the ruinous ecological impacts of waste transportation are limited simultaneously by exploiting a street, squander packs are moved to the last goal while travel time and environmental threatening are minimized. Proved that RIPv2 routing protocol can be deployed inside a medium range network infrastructure.

F. Posso, et al. 2017[8] focused on the Ecuadorian provinces with the most significant potential for diesel fuel-to-H2 replacement. To this end, the specific purpose of this work will be to create a preliminary technical overview to identify specific scenarios to be developed in future research and assessments.

K. Pardini, et al. 2019[9] advanced techniques for waste collection, and the use of technologies based on IoT and big data. There is also a vision of strengthening waste management based on public initiatives aimed at building more correct and safer environments, as well as reducing greenhouse gas emissions.

\section{Proposed Methodology:}

As mentioned early, the solid waste management is one of the costly urban services which require most of the municipal budgets, therefore the transportation cost of solid waste is considered as the main criterion to select the solid waste transportation route which can be reduced by managing and optimizing the waste transportation route. In this paper, a new proposed methodology has been introduced as shown in figure (1). This methodology used network analysis model to analyze the data obtained from the GPS technique to select the best transfer route. Developing of a new solid waste management method that will lead to investigate the aim and 
solving the problem by find the optimal transport routes to transport solid waste from transformer stations to final landfill sites through minimizing the distance, the time and the cost of transporting solid waste

\subsection{Data Collection}

In this, study data on different types of waste management facilities collected includes the following components. These real-time data allow to plan and optimize waste collection routes that can reduce the traveling distances of the waste transport vehicles.

It includes the transportation distances, waste transportation cost, duration of transfer the solid waste and quantities of generated waste number of shipments.

a. Transportation Distances (TD):

Baghdad districts are varying in distances and design. Baghdad municipality's vehicles carry out the transport of households, commercial and industrial wastes from transformer stations and then transportation to the final landfill sites.

b. Transportation Time: The total time consumed to transfer one shipment of solid waste from transformer stations to the landfill stations.

c. Number of shipments (Quantity of solid waste each month): shipment is a quantity of solid waste transported from the transformer station to the fin landfill stations.

d. Transportation Cost: Is the cost incurred for the transportation of solid waste to the landfill stations performed in a given period Transportation cost including all fuel, oil and maintenance cost of transportation vehicles.

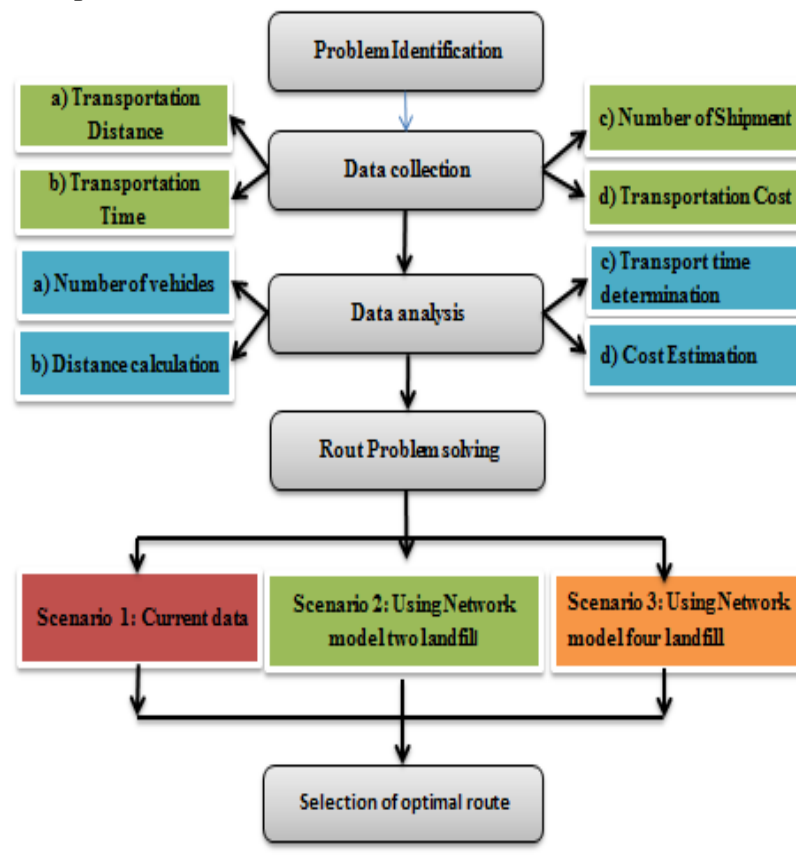

Figure 1: The Proposed Methodology

\subsection{Data Analysis:}

Data analysis is a procedure of reviewing, changing and demonstrating gathered information with the target of finding helpful data, the data collected can be divided into five sections (Calculate waste Quantities, Number of vehicles required, Distance Calculation, Real-time of transferring the solid waste and Cost Estimations), analyze and modeling them to obtain the required goal.

a. Calculate Waste Quantities:

In this work, we have adopted data for one season and because of the different number of shipments each month, we have calculated the rate of shipments per season for nine municipalities of Baghdad, we can calculate the number of tons per day by using equation(1).

\section{Number of tons per day $=$ $N_{S} * T_{S}$ \\ 30 day per month

$N_{S}=$ Number of shipments per month.

$\boldsymbol{T}_{\boldsymbol{S}}=$ Number of tons per shipment

b. Number of vehicles required $\left(N_{v}\right)$ :

To determine the number of vehicles required for each municipality, the number of shipments of solid waste in each municipality must be

Divided by the capacity of the vehicle in tons; it can be calculated by equation (2).

$$
\boldsymbol{N}_{\boldsymbol{v}}=\frac{Q_{w}}{S_{v}}
$$

$\boldsymbol{Q}_{w}$ : Quantity of waste generated (tons).

$S_{v}$ : Number of tons per shipment.

$\boldsymbol{N}_{\boldsymbol{v}}$ : Number of vehicles.

\section{c. Distance Calculation (DC):}

To calculate the distance traveled by the vehicle to transport waste, by monitoring the vehicle by a GPS device and connected to a particular mechanism to calculate the distance traveled to transfer one shipment from the transformer stations to the final landfill sites.

d. The real time of transferring the solid waste $\left(T_{v}\right)$ :

The real-time of transferring the solid waste is calculated by GPS devise for each shipment, according to the current plan of solid waste management between the transfer stations and landfill stations. There are only four sites of landfill stations Abu Ghraib, Nibaei, Nahrwan and Bueatha landfill station.

\subsection{Cost Estimations:}

It includes the cost of all services specifically incurred for transferring solid waste.The cost estimation of solid waste specifies for the vehicle type of Astra. In this study, the cost elements consist of (Fuel cost, oil cost, and maintenance cost).

- Fuel cost (FC): it is the price of fuel that consumed to move solid waste per kilometer. Baghdad municipality determines half a liter of fuel therefor the fuel cost calculation for each one kilometer as fallowing.

Fuel cost $=0.5$ liter $* \mathbf{P}_{\mathbf{f}}$

$$
\mathbf{P}_{\mathbf{f}}=\text { price of fuel }
$$

Price of one liter fuel $=400$ Iraq dinar (ID) therefor

$$
\text { Fuel cost of each kilometer = }
$$

\section{0,5 liter $* 400=200$ ID}

- Oil cost (OC): It refers to the price of oil used in the transportation vehicle to transfer the solid waste for landfill stations. According to the exchange mechanism used in the Municipality of Baghdad 
(Production Department) for vehicle oil that per 3000 kilograms 34 liters or approximately per kilo (0.011) liters so that the price is approximately 30 dinars per kilo.

- Maintenance Cost $\left(\boldsymbol{M}_{\boldsymbol{C}}\right)$ : Are the cost incurred to keep a vehicle in good condition or good working order. The maintenance cost of transportation vehicle is calculated by the production department and the mechanical plant responsible for the maintenance of vehicles included the maintenance cycle and the change of some parts per month approximately 1325000 , which is approximately daily 51000 thousand dinars. Therefor find the maintenance cost per kilometer determine the maintenance cost per day and divided this cost on the total distance of each municipality.

$$
\text { Maintenance cost }=\frac{(\text { monthly cost } / 30)}{\text { total distance }}
$$

Therefor the total cost per kilometer for fuel, oil and maintenance shows as follows:

$$
C_{t}=C_{f}+C_{o}+C_{m}
$$

$\boldsymbol{C}_{\boldsymbol{t}}:$ Final cost

$\boldsymbol{C}_{\boldsymbol{f}}$ : cost fuel per kilometer

$\boldsymbol{C}_{\boldsymbol{o}}$ : The cost of oil per kilometer

$\mathbf{C}_{\mathbf{m}}$ : Maintenance cost per kilometer

The total cost of transportation of solid waste per kilometer can be calculated as follow:

$$
C_{t}=200+30+620=850 \mathrm{ID} / \mathrm{km}
$$

The total cost of one day is calculated from equation (10) and the total cost per ton is calculated by equation (11)

$$
\begin{aligned}
& \boldsymbol{T}_{\boldsymbol{c}}=\boldsymbol{C}_{\boldsymbol{t}} * \boldsymbol{T}_{\boldsymbol{d}} * \boldsymbol{N}_{\boldsymbol{o v}} \ldots \ldots \ldots \ldots \ldots \ldots \ldots \\
& \boldsymbol{T}_{\boldsymbol{c}}: \text { Total cost per day (ID) } \\
& \boldsymbol{C}_{\boldsymbol{t}}: \text { Final cost }=850 \text { DI } \\
& \boldsymbol{T}_{\boldsymbol{d}}: \text { Traveled distance Km } \\
& \boldsymbol{N}_{\boldsymbol{o v}}: \text { Number of vehicles required } \\
& \boldsymbol{T}_{\boldsymbol{c} \boldsymbol{t}}=\frac{\boldsymbol{T}_{\boldsymbol{c}}}{\boldsymbol{Q}_{\boldsymbol{w}}} \ldots \ldots \ldots \ldots \ldots \ldots(\mathrm{f}) \\
& \boldsymbol{T}_{\boldsymbol{c} \boldsymbol{t}}: \text { Transport cost per ton (ID) } \\
& \boldsymbol{T}_{\boldsymbol{c}}: \text { Total cost per day (ID) } \\
& \boldsymbol{Q}_{\boldsymbol{w}}: \text { Quantity of waste ton } / \text { day }
\end{aligned}
$$

\subsection{Transportation Model}

To the motivation behind coming to objective was depended a theory that implying that apply quantitative strategies particularly transportation model for moving solid waste from transformer stations to conclusive landfill locales, based on daily will prompt abatement expenses of transport to the ideal levels and interest in taking care of the issue of transportation of solid waste in Baghdad city $[11,12]$.
1) $(\mathrm{m})=$ Source $($ Represents display centers. in our study the sources of solid waste production).

- $(\mathrm{n})=$ Destination (Represent demand centers. In our study the final landfill sites).

- (ai) = Quantity offered (The quantity supplied in each source i)

- $(\mathrm{bj})=$ Quantity required (Represents landfill capacity j).

- $($ xij) $=$ Number unit of Transfer (Represents the amount of waste transferred from source $i$ to site j).

- $(\mathbf{C i j})=$ Cost unit of yransport (represents the cost of transporting the unit from the transfer stations i to the final landfill site $\mathrm{j}$ )

2) Minimize $Z=\sum_{i-1}^{m} \sum_{j=1}^{n} c_{i j} \times x_{i j} . .(12)$

It means that the total cost of transferring solid waste from municipalities to different demand centers should be minimal.

$$
\begin{aligned}
& 3) \sum_{j=1}^{n} x_{i j}=a i, \quad i=1,2,3, \ldots m \\
& \sum_{j=1}^{m} x_{i j}=b j, \quad j=1,2,3 \ldots n \ldots \ldots \text { (8) }
\end{aligned}
$$

4) $\sum_{i=1}^{n} a i=\sum_{j-1}^{m} b j \ldots \ldots \ldots \ldots \ldots . . .(9)$

5) Minimize $\mathrm{Z}=\sum_{i=1}^{m} \sum_{j=1}^{n} c_{i j} \times x_{i j} \ldots \ldots . .(10)$

\section{Subject to:}

$$
\begin{gathered}
\sum_{i=1}^{m} x_{i j}=b i, \quad 1=1,2,3, \ldots, n \\
\sum_{j=1}^{n} x_{i j}=a i, \quad 1=1,2,3, \ldots, m
\end{gathered}
$$$$
x_{i j} \geq 0
$$

\section{Case study:}

In this research, Baghdad city selected as case study according to the solid waste problem. The governorate of Baghdad was the highest governorate in the population of 2018 with a population of $(8,126,755)$ and a percentage of $(21 \%)$ of the total population of the governorate. The population of urban areas in Baghdad $(7,110,234)$ was $87 \%$ of the total population of the governorate, while the population of rural areas $(1,016,521)$ was $13 \%$ (central statistical organizations Iraq) [10]. Distribution of the population of Iraq by governorate for 2018 shown in Figure (2).

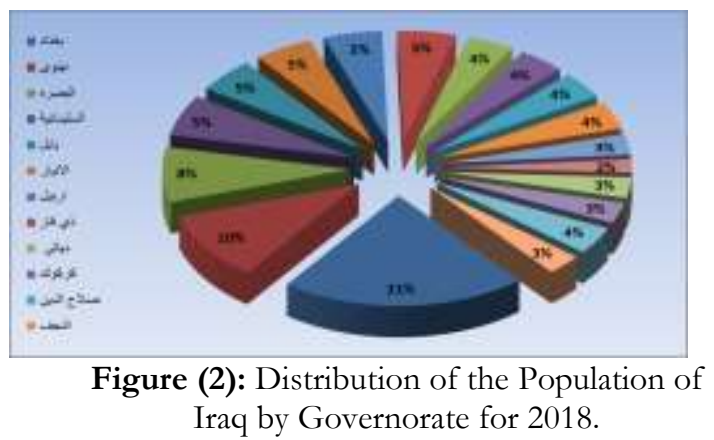

The Mayoralty of Baghdad is partitioned into fourteen regions (Beladiya). Baghdad mayoralties are shown in figure (3), as a map obtained from Baghdad mayoralty. 


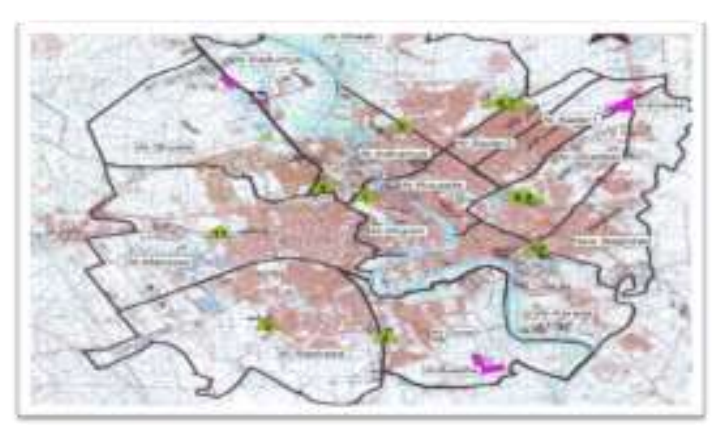

Figure (3): Map of Baghdad Municipalities

In our study we will address only municipalities that have a waste transformer station as show in figure (4)

\section{Municipalities}

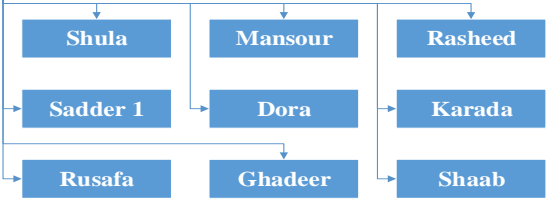

Figure (4): Municipalities That Have a Transformer Stations.

\subsection{Route Problem Solving:}

In this section, the solution method presented as a scenario of solution depending on the nature of the data obtained from the problem.

First, and second scenario are solved based on two landfill stations but the third scenario is solved based on four landfill stations which illustrated as follows:-

Scenario 1: Calculate the final costs according to the distribution mechanism of municipalities applied by Baghdad mayoralty based on GPS data.

Scenario 2: Optimize the route by transport model according to the distribution mechanism of municipalities applied by Baghdad mayoralty based on GPS data.

Scenario 3: Distribute municipalities for four landfill stations by using transport model based on GPS data

Scenario 1: we will clarify the mechanism of the mayoralty of Baghdad in the distribution of municipalities at the final landfill sites. According to the data obtained from the Mayoralty of Baghdad and analyzed previously, travel distance, real-time of one trip, a quantity of waste, number of vehicles required, total cost per day and transportation cost per ton in the table (1).

Table (1) Distribution of municipalities at the final landfill sites by GPS.

\begin{tabular}{|c|c|c|c|c|c|c|c|c|c|c|}
\hline & Municipalities & Landfill & $\begin{array}{c}Q W \\
\text { ton /day }\end{array}$ & $\begin{array}{c}\text { Nov } \\
\text { per day }\end{array}$ & $\underset{\text { trip } / \mathrm{km}}{T d}$ & $\begin{array}{c}\boldsymbol{T d} \\
\mathrm{day} / \\
\mathrm{km}\end{array}$ & $\underset{\text { trip } / \mathrm{km}}{T_{V}}$ & $\begin{array}{c}T_{V} \\
\text { day } / \mathrm{km}\end{array}$ & $\begin{array}{c}T c t \\
\text { ton/ (ID) }\end{array}$ & $\begin{array}{c}T c \\
\operatorname{day}(I D)\end{array}$ \\
\hline 1 & Al - Shula & Abu Ghraib & 180 & 9 & 82 & 738 & $2: 13: 18$ & 19:59:42 & 3485 & 627300 \\
\hline 2 & Al - Mansour & Abu Ghraib & 440 & 22 & 71 & 1562 & 1:56:03 & 42:33:06 & 3017 & 1327480 \\
\hline 3 & Al - Rasheed & Alnibaei & 404 & 21 & 142 & 2982 & $3: 48: 50$ & $80: 05: 30$ & 6274 & 2534696 \\
\hline 4 & Al-Dora & Abu Ghraib & 221 & 12 & 105 & 1260 & $2: 38: 27$ & $31: 41: 24$ & 4846 & 1070966 \\
\hline 5 & Al - Rusafa & Alnibaei & 120 & 6 & 123 & 738 & $3: 29: 28$ & $20: 56: 48$ & 5227 & 627240 \\
\hline 6 & Al - Sadder 1 & Alnibaei & 90 & 5 & 121 & 605 & 03:38:18 & 18:11:30 & 5713 & 514170 \\
\hline 7 & Al - karada & Alnibaei & 221 & 12 & 147 & 1764 & 04:05:36 & 49:07:12 & 6784 & 1499264 \\
\hline 8 & Al - Ghadeer & Abu Ghraib & 178 & 9 & 142 & 1278 & 03:50:25 & $34: 33: 45$ & 6102 & 1086156 \\
\hline 9 & Al - Shaab & Abu Ghraib & 101 & 6 & 129 & 774 & 03:36:10 & 21:37:00 & 6513 & 657813 \\
\hline \multicolumn{6}{|c|}{ Total (Distance, Time, Cost )per day (ID) } & 11701 & & $318: 45: 57$ & & 9287272 \\
\hline
\end{tabular}

\section{Scenario 2:}

Table (2) demonstrates the program interface and transportation costs for second scenario.

Table (3) from the solution obtained from WINQSB software, we discovered a change in some municipal trajectories for the landfill sites specified by the municipality of Baghdad.

In this scenario, the best transferring route is selected by using WINQSB software (network technique). Explains the distribution mechanism of Baghdad municipalities' to the final landfill sites, we note that a clear decrease in the time and final costs of transferring and landing of the solid waste as shown in the table (4).
Table (2) illustrating the program's interfaced and transport costs

\begin{tabular}{|l|r|r|r|}
\hline From \ To & Abu Ghraib & ALnibaei & \multicolumn{1}{|c|}{ Supply } \\
\hline AL- Shula & 3485 & 3910 & 180 \\
\hline AL- Mansour & 3017 & 5015 & 440 \\
\hline AL- Rasheed & 3932 & 6274 & 404 \\
\hline AL- Dora & 4846 & 5723 & 221 \\
\hline AL- Rusafa & 5610 & 5227 & 120 \\
\hline AL- Sadder 1 & 6138 & 5713 & 90 \\
\hline AL- Karada & 5630 & 6784 & 221 \\
\hline AL- Ghadeer & 6102 & 5973 & 178 \\
\hline AL- Shaab & 6513 & 6160 & 101 \\
\hline Demand & 1500 & 1500 & \\
\hline & & & \\
\hline
\end{tabular}


Table (3) Solution of Transport Model for second scenario

\begin{tabular}{|c|c|c|c|c|c|c|}
\hline $02-07-2020$ & From & To & Shipment & Unit Cost & Total Cost & Reduced Cost \\
\hline 1 & AL- Shula & Abu Ghraib & 180 & 3485 & 627300 & $\mathbf{0}$ \\
\hline 2 & AL-Mansour & Abu Ghraib & 440 & 3017 & 1327480 & $\mathbf{0}$ \\
\hline 3 & AL- Rasheed & Abu Ghraib & 404 & 3932 & 1588528 & $\mathbf{0}$ \\
\hline 4 & AL-Dora & Abu Ghraib & 221 & 4846 & 1070966 & $\mathbf{0}$ \\
\hline 5 & AL-Rusafa & ALnibaei & 120 & 5227 & 627240 & $\mathbf{0}$ \\
\hline 6 & AL- Sadder 1 & ALnibaei & 90 & 5713 & 514170 & $\mathbf{0}$ \\
\hline 7 & AL- Karada & Abu Ghraib & 221 & 5630 & 1244230 & $\mathbf{0}$ \\
\hline 8 & AL- Ghadeer & ALnibaei & 178 & 5973 & 1063194 & $\mathbf{0}$ \\
\hline 9 & AL- Shaab & ALnibaei & 101 & 6160 & 622160 & $\mathbf{0}$ \\
\hline 10 & Unfilled_Demand & Abu Ghraib & 34 & $\mathbf{0}$ & $\mathbf{0}$ & $\mathbf{0}$ \\
\hline 11 & Unfilled_Demand & ALnibaei & 1011 & $\mathbf{0}$ & $\mathbf{0}$ & $\mathbf{0}$ \\
\hline & Total & Objective & Function & Value $=$ & 8685268 & \\
\hline
\end{tabular}

Table (4): Final Solution of the second Scenario

\begin{tabular}{|c|l|c|c|c|c|c|c|c|c|c|}
\hline & Municipalities & Landfill & $\begin{array}{c}Q w \\
\text { ton /day }\end{array}$ & $\begin{array}{c}\text { Nov } \\
\text { per day }\end{array}$ & $\begin{array}{c}T d \\
\text { trip/km }\end{array}$ & $\begin{array}{c}T d \\
\text { day/ km }\end{array}$ & $\begin{array}{c}T v \\
\text { trip/ km }\end{array}$ & $\begin{array}{c}T v \\
\text { day/ km }\end{array}$ & $\begin{array}{c}T c t \\
\text { ton/ (ID) }\end{array}$ & $\begin{array}{c}T c \\
\text { day(ID) }\end{array}$ \\
\hline 1 & $\mathrm{Al}$ - Shula & Abu Ghraib & 180 & 9 & 82 & 738 & $2: 13: 18$ & $19: 59: 42$ & 3485 & 627300 \\
\hline 2 & $\mathrm{Al}-$ Mansour & Abu Ghraib & 440 & 22 & 71 & 1562 & $1: 56: 03$ & $42: 33: 06$ & 3017 & 1327480 \\
\hline 3 & $\mathrm{Al}$ - Rasheed & Abu Ghraib & 404 & 21 & 89 & 1869 & $2: 23: 22$ & $50: 10: 42$ & 3932 & 1588528 \\
\hline 4 & $\mathrm{Al}$ - Dora & Abu Ghraib & 221 & 12 & 105 & 1260 & $2: 38: 27$ & $31: 41: 24$ & 4846 & 1070966 \\
\hline 5 & $\mathrm{Al}$ - Rusafa & Alnibaei & 120 & 6 & 123 & 738 & $3: 29: 28$ & $20: 56: 48$ & 5227 & 627240 \\
\hline 6 & $\mathrm{Al}$ - Sadder 1 & Alnibaei & 90 & 5 & 121 & 605 & $03: 38: 18$ & $18: 11: 30$ & 5713 & 514170 \\
\hline 7 & $\mathrm{Al}$ - karada & Abu Ghraib & 221 & 12 & 122 & 1464 & $03: 23: 33$ & $40: 42: 36$ & 5630 & 1244230 \\
\hline 8 & $\mathrm{Al}$ - Ghadeer & Alnibaei & 178 & 9 & 139 & 1251 & $3: 45: 59$ & $33: 53: 53$ & 5973 & 1063194 \\
\hline 9 & $\mathrm{Al}$ - Shaab & Alnibaei & 101 & 6 & 122 & 732 & $3: 24: 34$ & $20: 27: 26$ & 6160 & 622160 \\
\hline
\end{tabular}

Scenario 3: Optimization of transport routes for four landfill sites can be obtained by GPS. (Albuaitha, Nahrwan, Abu Ghraib and Al_Nibaie) according to the data approved by the Baghdad mayoralty (GPS) distribution are shown in table (5).

We notice that using the distribution of municipalities to the four landfill sites and the use of GPS data significantly reduced cost and time compared to the previous scenario as shown in Table (6).

It is noted that the Distribution of municipalities to the four landfill sites data significantly reduces cost and time compared to the previous scenarios, as shown in Table (7).
Table (5) illustrating the program's interfaced and transport costs

\begin{tabular}{|c|c|c|c|c|c|}
\hline From \ To & $\begin{array}{c}\text { Abu } \\
\text { Ghraib }\end{array}$ & AL nibaei & $\begin{array}{c}\text { AL } \\
\text { bueatha }\end{array}$ & $\begin{array}{c}\mathrm{AL} \\
\text { nahrwan }\end{array}$ & Supply \\
\hline AL Shula & 3485 & 3910 & 3060 & 6885 & 180 \\
\hline AL Mansour & 3017 & 5015 & 2125 & 6205 & 440 \\
\hline AL Rasheed & 3932 & 6274 & 1678 & 5567 & 404 \\
\hline AL Dora & 4846 & 5723 & 1476 & 5353 & 221 \\
\hline AL Rusafa & 5610 & 5227 & 2380 & 3910 & 120 \\
\hline AL Sadder & 6138 & 5713 & 2833 & 4722 & 90 \\
\hline AL Karada & 5630 & 6784 & 1569 & 4153 & 221 \\
\hline AL Ghadeer & 6102 & 5973 & 2320 & 3438 & 178 \\
\hline AL SHaab & 6513 & 6160 & 3282 & 4241 & 101 \\
\hline Demand & 1500 & 1500 & 1000 & 1000 & \\
\hline
\end{tabular}

Table (6) Solution of transport model for the third scenario.

\begin{tabular}{|c|c|c|c|c|c|c|}
\hline 10-27-2019 & From & To & Shipment & Unit Cost & Total Cost & Reduced Cost \\
\hline 1 & AL Shula & Abu Ghraib & 180 & 3485 & 627300 & $\mathbf{0}$ \\
\hline 2 & AL Mansour & Abu Ghraib & 440 & 3017 & 1327480 & $\mathbf{0}$ \\
\hline 3 & AL Rasheed & AL bueatha & 404 & 1678 & 677912 & $\mathbf{0}$ \\
\hline 4 & AL Dora & AL bueatha & 221 & 1476 & 326196 & 0 \\
\hline 5 & AL Rusafa & AL bueatha & 64 & 2380 & 152320 & $\mathbf{0}$ \\
\hline 6 & AL Rusafa & AL nahrwan & 56 & 3910 & 218960 & $\mathbf{0}$ \\
\hline 7 & AL Sadder & AL bueatha & 90 & 2833 & 254970 & $\mathbf{0}$ \\
\hline 8 & AL Karada & AL bueatha & 221 & 1569 & 346749 & $\mathbf{0}$ \\
\hline 9 & AL Ghadeer & AL nahrwan & 178 & 3438 & 611964 & 0 \\
\hline 10 & AL SHaab & AL nahrwan & 101 & 4241 & 428341 & 0 \\
\hline 11 & Unfilled_Demand & Abu Ghraib & 380 & 0 & $\mathbf{0}$ & $\mathbf{0}$ \\
\hline 12 & Unfilled_Demand & AL nibaei & 1000 & $\mathbf{0}$ & $\mathbf{0}$ & $\mathbf{0}$ \\
\hline \multirow[t]{2}{*}{13} & Unfilled_Demand & AL nahrwan & 665 & $\mathbf{0}$ & $\mathbf{0}$ & $\mathbf{0}$ \\
\hline & Total & Objective & Function & Value $=$ & 4972192 & \\
\hline
\end{tabular}


Table (7): Final Solution of the third Scenario

\begin{tabular}{|c|c|c|c|c|c|c|c|c|c|c|}
\hline & Municipalities & Landfill & $\begin{array}{c}Q w \\
\text { ton /day }\end{array}$ & $\begin{array}{c}\text { Nov } \\
\text { per day }\end{array}$ & $\begin{array}{c}T d \\
\text { trip/Km }\end{array}$ & $\begin{array}{r}T d \\
\text { day/ } \\
\mathrm{Km} \\
\end{array}$ & $\begin{array}{l}\text { Tv trip/ } \\
\mathrm{Km}\end{array}$ & $\begin{array}{l}\mathrm{Tv} \text { day/ } \\
\mathrm{Km}\end{array}$ & $\begin{array}{c}\text { Tct } \\
\text { ton/ (ID) }\end{array}$ & Tc day(ID) \\
\hline 1 & $\mathrm{Al}$ - Shula & Abu Ghraib & 180 & 9 & 82 & 738 & $2: 13: 18$ & 19:59:07 & 3485 & 627300 \\
\hline 2 & $\mathrm{Al}$ - Mansour & Abu Ghraib & 440 & 22 & 71 & 1562 & $1: 56: 03$ & $42 ; 54: 06$ & 3017 & 1327480 \\
\hline 3 & $\mathrm{Al}$ - Rasheed & albueatha & 404 & 21 & 38 & 798 & 01:01:01 & $21: 35: 21$ & 1678 & 677912 \\
\hline 4 & Al-Dora & albueatha & 221 & 12 & 32 & 384 & $00: 51: 17$ & $10: 23: 24$ & 1476 & 326196 \\
\hline 5 & Al-Rusafa & albueatha & 64 & 3 & 56 & 168 & 01:35:28 & $05: 17: 48$ & 2380 & 152320 \\
\hline 5 & Al-Rusafa & Nahrwan & 56 & 3 & 92 & 276 & 02:36:04 & $08: 48: 12$ & 3910 & 218960 \\
\hline 6 & $\mathrm{Al}$ - Sadder 1 & albueatha & 90 & 5 & 60 & 300 & 01:48:18 & 14:01:30 & 2833 & 254970 \\
\hline 7 & $\mathrm{Al}$ - karada & albueatha & 221 & 12 & 34 & 408 & 00:57:14 & 11:26:48 & 1569 & 346749 \\
\hline 8 & $\mathrm{Al}$ - Ghadeer & Nahrwan & 178 & 9 & 80 & 720 & 02:10:13 & $19: 31: 57$ & 3438 & 611964 \\
\hline 9 & $\mathrm{Al}$-Shaab & Nahrwan & 101 & 6 & 84 & 504 & 02:21:09 & $14: 31: 34$ & 4241 & 428341 \\
\hline \multicolumn{6}{|c|}{ Total (Distance, Time, Cost)per day (ID) } & 5858 & & $125: 35: 41$ & & 4972192 \\
\hline
\end{tabular}

\section{Results and Discussion:}

This research first intended to identify the most suitable scenarios to solve the transportation problem of SWM from transfer stations into landfill sites in Baghdad city which chosen as a case study. An optimization of transport route selection has been carried out by employing the GPS and network analysis method.

Therefore, selection of an optimal transport route is based on the obtained results of actual real state of initial scenario (S1) and compared it along with two other suggested scenarios (S2, S3,). These final results of all supposed scenarios have been analyzing and represented that as shown in Table (8).

As explained in the table, the final results of scenarios will allow better service and contribute to significant gains for the transportation operation with reductions of total transport distance, transport time, and estimation costs respectively without mentioning the extra benefits related to fuel consumption, $\mathrm{CO}_{2}$ emissions maintenance of the vehicle, etc

Table (8): Final Results of all Supposed Scenarios.

\begin{tabular}{|c|c|c|c|c|c|c|}
\hline \multicolumn{2}{|c|}{ Total (Distance, Time,Cost) Per One year } \\
\hline No & Data & Software & Landfill & $\begin{array}{c}\text { Total } \\
\text { Distance/Km }\end{array}$ & $\begin{array}{c}\text { Total } \\
\text { Time/Hour }\end{array}$ & Total Cost/ID \\
\hline Scenario 1 & GPS & $\ldots \ldots$. & (AbuGhraib \& Nibaei) & 4212360 & 114755 & 3343417920 \\
\hline Scenario 2 & GPS & WinQsb & (AbuGhraib \& Nibaei) & 3678840 & 100302 & 2902718880 \\
\hline Scenario 3 & GPS & WinQsb & $\begin{array}{c}\text { (AbuGhraib, Nibaei, Nahrwan, } \\
\text { Bueatha) }\end{array}$ & 2108880 & 45214 & 1789989120 \\
\hline
\end{tabular}

The results obtained of supposed scenarios (S2, $\mathrm{S} 3$,) as shown in the previous table indicate that reduction of all input parameters studied (Distance, Time and Cost) compared with the initial state of scenario (S1). Therefore, we can see the final results of all assumed scenarios have a feasible solution that illustrates more accurate in the following figures $(5,6$ and 7).

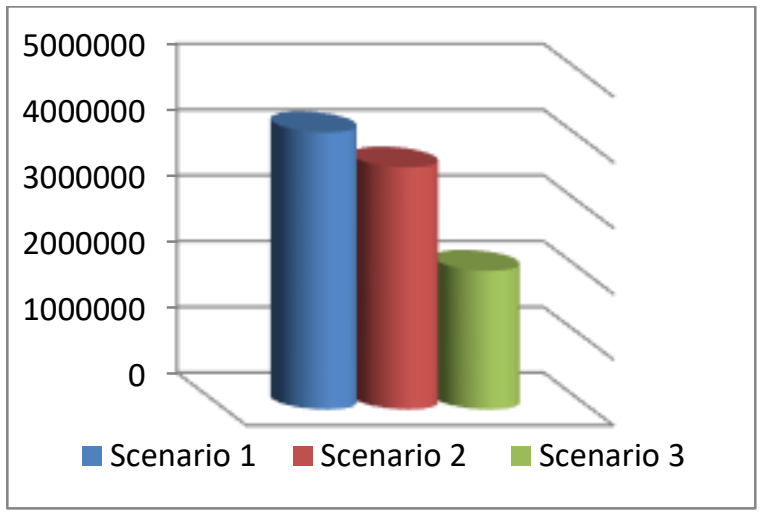

Figure (5): Final Results Distance of all Assumed

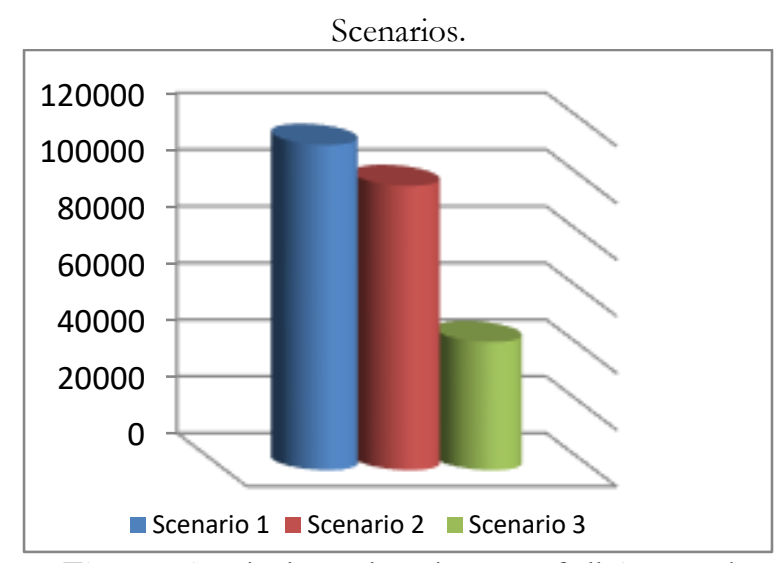

Figure (6): Final Results Distance of all Assumed Scenarios. 


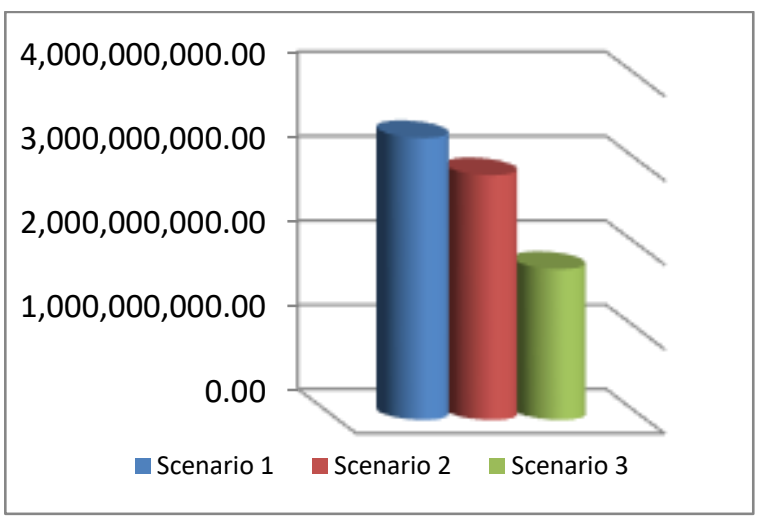

Figure (7): Final Results cost of all Assumed Scenarios.

\section{Conclusions}

Here are some future investigation proposals which can be received as a subsequent stage to the proposed model for the study zone.

1. Based on the data obtained from GPS and with the using of two landfill stations and solving the data by using Network transportation model, We note a decrease in the final cost (440699040ID) of transporting solid waste.

2. The use of the transportation model using four landfills resulted accomplished a decrease with solid waste transportation costs from its transformer stations to the final landfill sites where the interest has reached (1553428800ID)

3. Insufficient landfill sites in Baghdad, where there are only two regions (Abu Ghraib, AL Nibeai) which offer fewer options in transportation routes as some of them do not have other options that cause higher transportation costs.

4. The route of waste transport vehicles is random, and the best and economical route is not chosen, but the path is determined by the vehicle driver or staff.

5. Lack of paved roads for easy movement of vehicles transporting solid waste to final landfill sites and lack of a sufficient number of vehicles in landfill sites.

6. Finally, conclude the Scenario S3 is the best scenario of solution in this work, that include applied GPS and Network Analysis for four landfill sites.

\section{References:}

[1] J. A. Knowles, National solid waste management plan for Iraq, JO - Waste management \& research : the journal of the International Solid Wastes and Public Cleansing Association, ISWA, VL 27(4):322-7,2007

[2] M. Matotek and D. Regodic, "Software package Transp in the function of automatisation of transport management system," Singidunum J. Appl. Sci., vol. 10, no. 1, pp. 54-60, 2013.

[3] J. E. Santibañez-Aguilar, J. M. Ponce-Ortega, J. Betzabe González-Campos, M. Serna-González, and M. M. El-Halwagi, "Optimal planning for the sustainable utilization of municipal solid waste," Waste Manag., vol. 33, no. 12, pp. 2607-2622, 2013.

[4] O. I. Amariei, C. Hamat, L. Coman, and C. D.
Dumitrescu, "Approaching Modes Of Transport Problems Facilitated By The Use Of Winqsb Software," Int. Conf. Econ. Bus. Manag., vol. 2, no. February 2015, pp. 20-24, 2011.

[5] N. S. Hadi, "Analyzing Problem of Transporting The Solid Waste By Using The Method of Linear Programming 2009-2014 ( Case Study of Shatt AlArab District )," Vol. 6, No. 9, Pp. 116-127, 2015.

[6] [ T. P. B. Vecchi et al., "A sequential approach for the optimization of truck routes for solid waste collection," Process Saf. Environ. Prot., vol. 102, pp. 238-250, 2016.

[7] M. Rabbani, S. Sadri, and H. Rafiei, "Decision Science Letters," vol. 5, pp. 61-80, 2016.

[8] F. Posso, R. A. C. Narváez, J. Siguencia, and J. Sánchez, "Use of Municipal Solid Waste (MSW)Derived Hydrogen in Ecuador: Potential Applications for Urban Transportation," Waste and Biomass Valorization, vol. 10, no. 6, pp. 1529-1537, 2019.

[9] K. Pardini, J. J. P. C. Rodrigues, S. A. Kozlov, N. Kumar, and V. Furtado, "IoT-based solid waste

[10] C. S. O. Iraq, "Population Estimation of Iraq 2015 2018," 2018.

[11] H. A. taha, "operations research an introduction" in 8 th ed. new delhi: prentice, hall of india private limited, 2007.

[12]G. J. Hillier, Frederick S. And Liberman, Advance Praise For Introduction To Operations Research ,2001. 